Relations industrielles

Industrial Relations

\title{
The Industrial Composition of Income and Product, by John W. Kendrick, editor, National Bureau of Economic Research, Columbia University Press, New York, 1968, 494 pages.
}

\section{René Parenteau}

Volume 23, numéro 4, 1968

URI : https://id.erudit.org/iderudit/027972ar

DOI : https://doi.org/10.7202/027972ar

Aller au sommaire du numéro

Éditeur(s)

Département des relations industrielles de l'Université Laval

ISSN

0034-379X (imprimé)

1703-8138 (numérique)

Découvrir la revue

Citer ce compte rendu

Parenteau, R. (1968). Compte rendu de [The Industrial Composition of Income and Product, by John W. Kendrick, editor, National Bureau of Economic Research, Columbia University Press, New York, 1968, 494 pages.] Relations industrielles / Industrial Relations, 23(4), 705-706.

https://doi.org/10.7202/027972ar

Tous droits réservés (C) Département des relations industrielles de l'Université Laval, 1968
Ce document est protégé par la loi sur le droit d'auteur. L'utilisation des services d'Érudit (y compris la reproduction) est assujettie à sa politique d'utilisation que vous pouvez consulter en ligne.

https://apropos.erudit.org/fr/usagers/politique-dutilisation/ 
La raison du choix des directeurs de compagnies pour fonder une telle étude est simple; un tel choix permet d'abord d'éclaircir une situation devenue de plus en plus embrouillée, de comprendre pourquoi et dans quelle mesure la rémunération des directeurs a fait place à de multiples formes de compensation. Ce choix permet ensuite de soisir l'impact des taxes et de l'impôt sur l'augmentation du revenu réel des salariés les plus fortement rémunérés dans l'économie. Enfin, une telle étude limitée à des directeurs de compagnies fait intervenir un outre problème cuisant, celui de la motivation même des directeurs, ce groupe dont l'intéressement a une portée si grande sur le développement des économies nationales.

Les conclusions et résultats de recherche de Lewellen étonnent. Pour éviter les charges écrasantes de l'impôt progressif, les directeurs ont opté pour d'autres formes de compensation que les salaires et bonus; en 1963, par exemple, moins de la moitié de la compensation après la taxe des directteurs était composée des salaires et bonus. Ces outres formes de compensation (actions préférentielles, paiements différés, bénéfices de pension, plans de partage des profits) non seulement permettent aux directeurs de jouir d'exemption de taxes, mais aussi leur accordent une nouvelle position stratégique dans l'entreprise égale à celle des entrepreneurs et des actionnaires privilégiés.

En outre, les résultats statistiques sont ainsi regroupés qu'ils permettent d'établir une évolution historique de la compensation des directeurs depuis la guerre, une comparaison entre les compagnies, une comparaison entre la compensation des cadres inférieurs et celle des cadres supérieurs de I'industrie.

La partie méthodologique de la recherche nous résume toutes les formes et tous les plans d'exemption de taxes et d'avantages supplémentaires des directeurs de compagnies; la partie empirique de l'analyse nous donne la mesure et l'extension qu'ont pris ces plans. Enfin, six appendices ajoutent à cette information six analyses détaillées concernant l'utilisation de plans particuliers et les techniques utilisées pour calculer le bénéfice total.

\section{René PARENTEAU}

The Industrial Composition of Income and

Product, by John W. Kendrick, editor, National Bureau of Economic Research,

Columbia University Press, New-York, 1968, 494 pages.
Cet ouvrage contient les textes exposés à la « Conference on the Industrial Composition of Income and Product tenue en décembre 1966. Ces textes représentent des études basées sur de nouveaux estimés rapportés dans les comptes nationaux. Ces nouveaux estimés rendaient possible l'analyse des changements survenus dans la structure économique car ils présentaient en dollars courants et constants le produit national par industrie et des tables comparatives entre l'investissement et la production, entre le revenu et la dépense, car ils présentaient en somme la valeur ajoutée produite par chaque industrie.

Toute étude qui part de ces nouveaux estimés peut donc s'avérer d'un grand intérêt non seulement pour analyser les changements passés dans les structures économiques, mais aussi pour prévoir des mouvements futurs... n'est-ce pas là une autre démarche importante vers la planification du développement économique. Outre une étude nouvelle de l'économie nationale, toute recherche en ce sens peut maintenant analyser quantitativement des phénomènes non purement économiques du développement économique, tels les changements technologiques, I'innovation, la requalification et l'utilisation nouvelle de la main-d'oeuvre. Voilà les principales qualités des trois études présentées dans ce recueil.

Première partie: "Changes in Final Demand, Industry Product, and Prices $\gg$. Cette première étude cherche ò expliquer les changements des prix survenus entre les années 1958-1964, à analyser les causes des changements de la composition du produit réel au cours des années 1947-1958. La première onalyse, celle d'Alterman, étudie les changements des prix surtout en fonction des variations de la valeur ajoutée; elle développe également l'utilisation des tables * revenu-dépense » pour expliquer les changements des prix. La seconde analyse explique les changements dans la production industrielle; les auteurs, Vaccara et Simon, concluent que le principal facteur de ces phénomènes est la demande plus que les changements des coefficients techniques.

Deuxième partie: "Changing Factor Costs and Shares of Cross Income by Industry $\mathbf{x}$. Greenberg and Mark étudient d'abord les différences des coûts des facteurs par industrie selon deux critères, les gains moyens par heure de travail et la production par homme-heure. Ils comparent ensuite les fructuations entre les années 1947-1960 et les expliquent par le niveau moyen comparé de l'emploi, par lo technicité particulière à 
chaque entreprise et par le temps moyen de travail par entreprise.

Ensuite, Kendrick complète cette étude par une analyse des changements des coûts dans l'industrie autres que ceux de la maind'oeuvre (taxes, prix du capital, productivité du capital, etc.). Enfin, Egbert fait une analyse du partage des profits par les différents facteurs de l'industrie, et des changements survenus dans ce partage ou cours des années.

Troisième partie: "Basic Industry Product Estimates ». Les études de cette partie sont consacrées surtout à la discussion et à l'utilisation des estimés de base. Gottsegen et Ziemer décrivent le concept basique et les méthodes utilisées pour évaluer le produit brut par industrie. Gehman et Motheral décrivent I'indexe numérique (Federal Reserve Bulletin) de production selon des regroupements particuliers de marché (biens de consommation, équipement et matériel). Enfin, Gartson et Worton exposent les difficultés $d^{\prime}$ isoler des mesures de la production domestique (industrie canadienne) et décrivent les progrès en ce sens par la table des nouvecux estimés.

Signalons finalement le grand nombre de tableaux et d'histogrammes qui illustrent bien la richesse des données statistiques et leurs multiples utilisations.

\section{René PARENTEAU}

\section{Employee Compensation under the Income}

Tax, by C. Harry Kahn, National Bureau of Economic Research Inc., New York, 1968,142 pp.

The object of this study is to examine the impact of the personal income tax on employee compensation, the latter's importance as a source of tax revenue, and the reasons for the striking changes which have taken place over the last two decades in the share of income tax revenue attributable to employees compensation.

This study is organized around four major topics. First, as a prelude to discussing its share in personal income tax revenue, the author examines the relative coverage of wage and salary income on tax returns and its effects on the share of total income reported. In second place, the size distribution and composition of income reported on returns with wages and salaries are investigated. This was done to identify relevant income characteristics of the tox- payers who are the recipients of wages and salaries. Third, the effects of and reasons for the major statutory provisions which have at one time or another been aimed at the tax treatment of employee compensation are discussed. Finally, the author presents estimates of the tax liability attribuable to wages and salaries for a period of thirty-five years and analyse their share in total tox liability in the light of the informotion in earlier chapters.

The study, which covers the 35 years period from 1939 to 1964, shows how wages and salaries differ from other income sources in their coverage on tox returns, in their distribution by income size groups, and in the legal provisions affecting their inclusion in the statutory concept of income. Attention is also given to special problems in the taxation of wages and salaries, such as taxes on the income of working wives, earned, versus unearned income, excludable sick pay, and deferred compensation.

This report is the tenth in the Nationo Bureau's series of fiscal studies.

\section{Pierre DIONNE}

\section{Managing Intergroup Conflict in Industry,} by Robert R. Blake, Herbert A. Shepard et Jane S. Mouton, Gulf Publishing Co., Houston, Texas, 1964, 210 pages.

Tous ceux qui occupent un poste de direction quelconque formulent habituellement les deux mêmes critiques envers les sciences du comportement: en plus de reconnaître que les connaissances dans ce comaine sont éparpillées dans une foule de volumes de nature différente, les cadres reprochent oux théoriciens de ne pas se pencher suffisamment sur leurs préoccupations pratiques et quotidiennes. II n'est alors pas surprenant de constater les grandes difficultés d'appli. cation des conclusions prônées par les théoriciens des sciences du comportement.

Pour tenter de résoudre ce problème d'adaptation de la théorie au monde pratique, les auteurs ont écrit ce livre spécialement pour les « managers $»$.

Pour ce faire, Blake, Shepard et Mouton

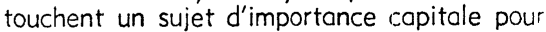
les dirigeants. Ils proposent comment atteindre une coordination efficace entre les diverses parties d'une organisation telles que la direction et le syndicat, les ventes et lo production. la ligne hiérarchique et les fonctions conseils, enfin entre le siège social et les filiales. 